A N N A L E S

UNIVERSITATIS MARIAE CURIE-SKŁODOWSKA

LUBLIN - POLONIA

VOL. LXVI, 2

SECTIO G

2019

Uniwersytet im. Adama Mickiewicza w Poznaniu

MARIA ZMIERCZAK

mariaz@amu.edu.pl

ORCID: 0000-0003-1116-3561

\title{
Wojna i jej skutki jako ideologiczne źródło europejskiego faszyzmu
}

War and Its Effects as an Ideological Source of European Fascism

Z perspektywy niemal stulecia pochodzące z lat 30. XX w. hasło: „Faszyzm to znaczy wojna", przypisywane angielskiemu politykowi Johnowi Stracheyowi ${ }^{1}$, wydaje się niezwykle trafne. Zawarta w nim teza o nierozerwalnym związku faszyzmu z wojną powtarzana jest także we współczesnych opracowaniach naukowych. Robert O. Paxton stwierdził wyraźnie, że „Doświadczenie pierwszej wojny światowej było najbardziej decydującym bezpośrednim warunkiem wstępnym dla rozwoju faszyzmu" ". Chciałabym wyjaśnić, że terminu „faszyzm” używam tutajpodobnie jak Paxton, Robert Eatwell, Jerzy W. Borejsza ${ }^{3}$ i wielu innych badaczy - w znaczeniu rodzajowym, a nie jako nazwy własnej stosowanej na określenie fenomenu włoskiego. Stoję bowiem na stanowisku, iż faszyzm włoski i podobne do niego ruchy były zjawiskiem powszechnym w Europie po I wojnie światowej, choć nie wszędzie wyrosły do rangi ugrupowań sprawujących władzę i do rangi reżimów totalitarnych, nie wszędzie też przybrały taką samą postać. Wszystkie jednak - co będę usiłowała wykazać - miały z wojną wiele wspólnego. Oczywiście wśród tych ruchów pierwszym były Fasci Italiani di Combattimento, ruch

1 J. Strachey (1901-1963) - angielski polityk, rozpoczął swą karierę jako zwolennik Oswalda Mosleya, następnie był w partii komunistycznej, a skończył jako laburzystowski poseł, od lat 30. był przeciwnikiem faszyzmu. O przypisaniu mu tej frazy zob. H. Markiewicz, A. Romanowski, Skrzydlate słowa. Wielki stownik cytatów polskich i obcych, Kraków 2005, s. 396.

2 R.O. Paxton, Anatomia faszyzmu, Poznań 2005, s. 34.

3 Zob. Faszyzmy europejskie (1922-1945) w oczach współczesnych i historyków, wyb. i wstęp J.W. Borejsza, Warszawa 1979. 
założony przez Benito Mussoliniego w 1919 r. i dopiero w 1921 r. przemianowany i zarejestrowany jako Partito Nazionale Fascista. Wkrótce potem, w 1920 r., powstała NSDAP, ale wspomnieć należy i o innych, takich jak: założona przez Corneliu Zeleę Codreanu w 1922 r. Liga Obrony Narodowej i Chrześcijańskiej ${ }^{4}$, znana od 1927 r. jako Legion Archanioła Michała, z którego później wyrosła Żelazna Gwardia (Garda de Fer); organizacja REX Léona Degrelle'a; Partia Strzałokrzyżowców Ferenca Szálasiego. Bodaj nie było w Europie kraju, gdzie takie ruchy by się nie pojawily, choćby jako szybko spacyfikowane bądź zdelegalizowane marginalne ugrupowania ${ }^{5}$. Moją tezą jest, że wprawdzie intelektualnych źródeł różnych idei, które ruchy faszystowskie wykorzystały - takich jak rasizm, antysemityzm, darwinizm społeczny, nietzscheanizm ${ }^{6}$, pochwała przemocy, krytyka demokracji, obawa przed bolszewizmem i przede wszystkim pojmowanie narodu jako obiektywnego bytu - można doszukiwać się na długo przed I wojną światową, to jednak właśnie ona nadała im nowy kształt, mianowicie dlatego, że stały się one popularne szczególnie w wyniku przebiegu i skutków tej wojny. Stanowiły podstawę działania politycznego, a przedtem były raczej dziełem intelektualistów. Niektórzy badacze wręcz uważają, iż największym źródłem idei przyswojonych przez rozmaite faszyzmy była Francja, z takimi jej przedstawicielami, jak Charles Maurras, Georges Sorel, Maurice Barrès i wielu innych 7 . Pochwała wojny pojawiła się jednak przede wszystkim u Sorela, który głosząc ideę strajku generalnego i pochwałę przemocy proletariackiej, jaką winni się posłużyć syndykaliści dla obalenia państwa, twierdził, że wojna jest czymś szlachetnym, lepszym od państwa, które posługuje się katami. Często można w jego pracach odnaleźć pochwałę czystych i prostych aktów wojny, w których „,iła przejawia się zgodnie ze swą naturą, nie próbując zapożyczać niczego od procedur prawnych, które społeczeństwo stosuje wobec przestępców" ". Analizując ruchy faszystowskie, z pew-

4 Na temat faszyzmu rumuńskiego bardzo interesujące jest niedawno wydane studium Mihai Chioveanu Sacralizing the Nation. The Political Messianism of the Legion "Archangel Michael" ([w:] Vers un profil convergent des fascisms. « Nouveau consensus » et la religion politique en Europe centrale, sous la dir. de Traian Sandu, Paris 2010, s. 83-107).

5 Odsyłam do nadal aktualnego studium Stanleya Payne'a Fascism. Comparison and Definition (Madison 1980, passim) oraz do bardziej szczegółowego opisu tych ruchów w pracy M. Zmierczak Spory o istotę faszyzmu. Dzieje i krytyka (Poznań 1988, s. 171-189).

6 Nawet zdając sobie sprawę z fałszerstw, jakich dokonali naziści na dziełach Friedricha Nietzschego, nie można zaprzeczyć, że wiele jego sformułowań wykorzystano w propagandzie, nie tylko zresztą w Niemczech, ale i we Włoszech. Zob. M. Baranowska, Nazizm kontra Nietzsche, „Studia nad Faszyzmem i Zbrodniami Hitlerowskimi” 2008, t. 30, s. 37-62.

7 Najbardziej wyraziście tę tezę wyłożył Zeev Sternhell w pracy La droite révolutionnaire, 1885-1914: les origines françaises du fascisme (Paris 1978).

8 Zob. G. Sorel, Réflexions sur la violence, Paris 1925, s. 161. Dla Sorela głównym przeciwnikiem było państwo, zwłaszcza rządzone przez socjalistów parlamentarnych, państwo bowiem posługuje się katami i surowym prawem. W tym kontekście umieścił fragment o rewolucji proletariackiej jako pięknej i prawej wojnie. Cały passus brzmi: „Les violences prolétariennes n'ont aucun 
nością nie można abstrahować od faktu, że pojawiły się one właśnie po I wojnie światowej - wywarła na nie bowiem duży wpływ i można powiedzieć, że stała się „promotorką" faszyzmów europejskich w trojakim wymiarze.

Po pierwsze, wojna bardzo wzmocniła nacjonalizm, wskazała na konieczność identyfikacji narodowej przede wszystkim poprzez przesłanie Woodrowa Wilsona o prawie do samostanowienia narodów. Wprawdzie nie łączył on terminu „naród” z jednością rasową, językową czy religijną, używał terminu people z pewnością w znaczeniu wspólnej woli politycznej, ale akurat w Europie, a zwłaszcza w Europie Środkowej i Wschodniej, już bardzo popularne było rozumienie jedności narodowej nie tyle jako woli wspólnoty politycznej, ile jako jedności duchowej, rasowej itd. Wydaje się, że po I wojnie światowej argumentacja Ernsta Renana odwołująca się do wspólnoty pojmowanej jako wspólna wola i poczucie obowiązku wobec historycznej wspólnoty losu została bardzo szybko zapomniana, można powiedzieć - skompromitowana. Generalizując, można chyba zasadnie stwierdzić, że I wojna światowa okazała się końcem pewnych liberalnych idei, a już z pewnością podważyła twierdzenie, że jednostka ma wartość sama w sobie; jej wartość wynikała odtąd z przynależności do narodu i jego wartości.

Po drugie, postanowienia pokojowe wywołały dość powszechne niezadowolenie, na które jeszcze nałożyły się problemy społeczne i ekonomiczne.

Po trzecie wreszcie, wojna wywarła wpływ na całą generację, która brała osobiście udział w walkach9. Wielu późniejszych działaczy ruchów faszystowskich uczestniczyło w tej wojnie. Można wprawdzie użyć kontrargumentu, iż post hoc nie oznacza propter hoc, ale jednak faszystowskimi przywódcami nie zostawali ludzie, którzy udział w wojnie potępiali czy krytykowali. Wojna została poddana zabiegom estetyzującym. Jak nigdy wcześniej pojawiła się pochwała wojny, siły, mocy, a sami przywódcy różnych ruchów faszystowskich wprowadzali elementy militaryzacji ruchów, takie jak dyscyplina, tworzenie oddziałów paramilitarnych, umundurowanie swoich członków, a także organizowanie licznych marszów, które miały przypominać przemarsze wojsk.

rapport avec ces proscriptions; elles sont purement et simplement des actes de guerre, elles ont la valeur de démonstrations militaires et servent à marquer la séparation des classes. Tout ce qui touche à la guerre se produit sans haine et sans esprit de vengeance; en guerre on ne tue pas les vaincus; on ne fait pas supporter à des êtres inoffensifs les conséquences des déboires que les armées peuvent avoir éprouvées sur les champs de bataille; la force s'étale alors suivant sa nature, sans jamais prétendre rien emprunter aux procédures juridiques que la société engage contre les criminels".

9 O. Bauer (Faszyzm, 1936/1938, cyt. za: Faszyzmy europejskie ..., s. 206) pisał: „[...] po pierwsze, wojna światowa wykoleiła i zdeklasowała masy swoich uczestników; znaleźli się oni poza nawiasem normalnego, mieszczańskiego życia. Niezdolni do tego, by powrócić do dawnych, mieszczańskich form życia i zarobkowania, przywiązani do form życia i do ideologii nabytych w czasie wojny, tworzyli w okresie bezpośrednio po wojnie kadrę faszystowskich »milicji«, ultraprawicowych »związków zbrojnych« - o swoistej militarystycznej, antydemokratycznej, nacjonalistycznej ideologii”. 
Niewątpliwie ogromne znaczenie miał charakter I wojny światowej. Nie bez przyczyny została ona w pamięci zwłaszcza Europejczyków utrwalona jako „Wielka Wojna”, „la Grande Guerre”. Rzeczywiście była największą z dotychczasowych, przede wszystkim ze względu na wciągnięcie do niej mas ludzi ponad $65 \mathrm{mln}$ ludzi zostało zmobilizowanych, a straty ludzkie były większe niż kiedykolwiek przedtem. Wojna ta dotknęła też ludność cywilną w stopniu dotychczas niespotykanym ani podczas wojen napoleońskich, ani podczas wojny francusko-pruskiej. Istotną rolę odegrało lotnictwo, po raz pierwszy użyte w walkach, co także stanowiło novum. Przez swą masowość wojna spowodowała ogromny wzrost aktywności państwa, natomiast konsekwencje społeczno-ekonomiczne zupełnie podważyły paradygmat liberalny - ludzie musieli identyfikować się przede wszystkim jako część narodu, ważniejsza od jednostki stawała się grupa, najczęściej tworząca masę. Wojna zakończyła się również wielkim wybuchem na wschodzie, rewolucja komunistyczna była bowiem jej istotnym elementem. Zjawisko, jakim stał się „ornament z masy ludzkiej”, było przedmiotem namysłu zarówno Siegfrieda Kracauera, jak i José Ortegi y Gasseta ${ }^{10}$.

Ład ustalony $\mathrm{w}$ traktacie wersalskim i w powiązanych z nim traktatach zawartych z poszczególnymi państwami miał zapewnić trwały pokój, opierając się na zasadzie samostanowienia narodów i ograniczając zbrojenia. Nie było przypadkiem, że część pierwsza traktatu dotyczyła powołania Ligi Narodów, która miała zapewnić pokojowe rozstrzyganie sporów międzynarodowych; traktat powołał też do życia Międzynarodową Organizację Pracy, która w jakimś stopniu miała zadbać o interesy ludzi pracy. Można powiedzieć, że utworzenie Ligi Narodów oraz dążenie do pokojowego rozstrzygania sporów były wyrazem pacyfizmu, a także wywarły wielki wpływ na kształt, rozwój i znaczenie prawa międzynarodowego ${ }^{11}$. Powiedziałabym, że ten pacyfizm był określony przez liberałów i na warunkach oświeceniowego liberalizmu. Niewątpliwie symbolem takich dążeń we Francji był Aristide Briand ${ }^{12}$. Miał on jednak przeciw sobie znaczną część Europy; w sa-

10 Kracauer w tekście z 1927 r. pt. Ornament z ludzkiej masy ([w:] Wobec faszyzmu, wyb. i wstęp H. Orłowski, Warszawa 1987, s. 11-22) odnosi się teoretycznie do zjawiska masowości jako typowego dla kapitalizmu, natomiast Ortega y Gasset w Buncie mas i innych pismach socjologicznych (Warszawa 1982, s. 48 i n.) wiąże masowość zarówno z faszyzmem, jak i z komunizmem.

11 M. Zmierczak, Der Einfluss des Ersten Weltkrieges auf die Entwicklung des Völkerrechts, [w:] Der Traum vom Frieden - Utopie oder Realität? Kriegs- und Friedensdiscurse aus historischer, politologischer und juristischer Perspektive (1914-2014), Hrsg. E. Dácz, Ch. Griessler, H. Kovács, Budapest 2016, s. 151-163.

12 Zob. Aristide Briand, la Société des Nations et l'Europe 1919-1932. Publié sous la direction de Jacques Bariéty, Strasbourg 2007. Publikacja ta zawiera wiele artykułów omawiających pacyfistyczne dążenie Brianda do zapewnienia „pokoju przez prawo”. 
mej Francji powstało sporo ruchów, które atakowały słabą demokrację. Było ich wiele - od Action Française, przez Croix-de-Feux, po Parti populaire français. Można powiedzieć, że te ruchy faszystowskie wyrażały przede wszystkim niezadowolenie z powstałego status quo. Traktat wersalski był przedmiotem stałej i dość powszechnej krytyki. Krytyka niesprawiedliwego traktatu widoczna była u faszystów włoskich, którzy niezmiennie mówili o vittoria mutilata. Na krytyce traktatu wyrastał ruch Hitlera, który w licznych mowach wciąż używał terminu „dyktat wersalski” i stale nawiązywał do twierdzenia o ciosie w plecy zadanym armii niemieckiej przez „listopadowych zdrajców”"13, co umacniało poczucie krzywdy w społeczeństwie niemieckim (tzw. Dolchstosslegende). Niezadowolenie Francuzów, potęgi przecież zwycięskiej, wypływało z faktu, iż przez całą wojnę krążyło powiedzenie: „Szwab zapłaci”. Tymczasem sprawa repartycji, jak wiadomo, bardzo mocno się rozmywała ${ }^{14}$. Mając w pamięci ogromną sumę, jaką Francuzi zapłacili po przegranej wojnie z Prusami, wyobrażano sobie, że teraz będzie podobnie. Niezadowolenie było powszechne. Przykładem mogą być Węgrzy, którym polityka Ententy odebrała ogromną część terytorium, a poza granicami okrojonych Węgier znalazła się jedna trzecia narodu węgierskiego - oni także uważali traktat wersalski i zawarty w dniu 4 czerwca 1920 r. traktat z Trianon za niesprawiedliwy ${ }^{15}$. To samo dotyczyło Austriaków, którym traktat zawarty w dniu 10 września 1919 r. w Saint German-en-Laye zakazywał połączenia się z państwem niemieckim. Również Słowacy czuli się pokrzywdzeni, a to dlatego, że nie udało im się stworzyć własnego państwa. Istotnym elementem w wielu państwach Europy Środkowej była krytyka małego traktatu wersalskiego, który gwarantował prawa obywatelskie wszystkim mniejszościom narodowym czy religijnym, a przede wszystkim Żydom. Było to ważne w społeczeństwie rumuńskim ${ }^{16}$, ale też w Polsce. Jednym słowem, przeważało rozczarowanie traktatem, które ruchy faszystowskie bezwzględnie eksploatowały.

13 Jeden z propagandystów ideologii nazizmu, Alfred Rosenberg, napisał nawet pamflet Novemberköpfe (München 1927), w którym stale posługiwał się określeniem Novemberverbrecher wobec polityków niemieckich, którzy podpisali traktat wersalski, oraz wobec rządzących w Republice Weimarskiej.

${ }^{14}$ G. Lefebvre, Ch.H. Pouthas, M. Baumont, Historia Francji, t. 2: Od 1774 do czasów wspótczesnych, Warszawa 1969, s. 479. Autorzy wskazują, że żądania odszkodowań od Niemiec były często fantastyczne, a francuski minister finansów Klotz głosił, że „Le boche payera tout”.

15 Zob. M. Seidler, Hungary and the League of Nations, [w:] Der Traum vom Frieden..., s. $187-198$.

16 Mara Magda Maftei-Bourbonnais (Cioran, compagnon de route de la Garde de Fer, [w:] Vers un profil convergent des fascisms..., s. 111) wskazuje, że uważano, iż konstytucja z 1923 r. „vendu la Roumanie aux grandes puissances par l'acceptation du Traité de protection des minorités de 1919 et la garantie des droits politiques et civils pour les minorités nationales. La formation d'une nation pure, sans les minorités héritées le 1 décembre 1918, le jour de l'unification de toutes les provinces roumaines, ne représentait pas seulement le desideratum du légionarisme, qui toléraient d'une manière tacite la manifestation de cet extrémisme chez les legionnaires". 
Ważnym skutkiem I wojny światowej było to, że upadły stare monarchie, stare struktury. Skutkiem pośrednim była rewolucja bolszewicka, która w momencie podpisania traktatu wprawdzie nie wydawała się zwycięska, lecz trwała, dla jednych była wspaniałym przykładem zwycięstwa proletariatu, a dla innych horrorem bolszewizmu. Te dwa elementy miały wpływ zarówno na ich powstanie, jak i na formułowane dążenia we wszystkich ruchach faszystowskich. W programach tych ruchów dwa elementy były istotne: postulaty narodowe połączone z postulatami społecznymi. Zgadzam się z opinią Rogera Eatwella, że faszyzmy, a ściślej - ruchy faszystowskie, proponowały i propagowały rozwiązanie problemów społecznych, składały obietnicę wyboru trzeciej drogi przeciw komunizmowi i socjalizmowi, ale też przeciw klasycznemu liberalizmowi wolnorynkowemu. Ruchy faszystowskie w Europie łączyły te postulaty, choć moim zdaniem niekoniecznie je realizowały, a w zależności od tego, do jakiej definicji narodu sięgały (rasistowskiej czy darwinistycznej), taką potem realizowały politykę.

Wart wspomnienia jest również udział w I wojnie światowej często wybitnych działaczy różnych ruchów faszystowskich. Można powiedzieć, że właśnie dla nich wojna stała się ważnym elementem kreującym ich osobowość, co w powiązaniu z faktem, iż ruchy te były oparte na charyzmie wodza, miało ogromny wpływ na funkcjonowanie samych ruchów faszystowskich. Mussolini nawoływał do wojny i sam wziął w niej udział. Uważał, mimo że był socjalistą, iż uczestnictwo w wojnie jest konieczne dla sprawy rewolucji i dlatego porzucił żądanie neutralności. Wbrew pozorom był dość długo na wojnie. W dniu 31 sierpnia $1915 \mathrm{r}$. dostał powołanie, a już 2 września wysłano go na front w okolice Isonzo; był szeregowcem w 11. pułku bersalierów, kapralem został w 1916 r., ale 23 lutego 1917 r. został poważnie ranny i w kwietniu wrócił jako bohater wojenny do Mediolanu. Wprawdzie został ranny w trakcie ćwiczeń, ale rana była poważna ${ }^{17}$. Dla Hitlera wojna była przeżyciem bodaj największym. Znana jest słynna fotografia, wykorzystywana później przez nazistowską propagandę, na której stojący w tłumie młody Hitler z promieniejącą radością twarzą słucha informacji o wybuchu wojny. Wiadomo też, że służył dzielnie i wykazał się odwagą w pułku Lista ${ }^{18}$. Norman Davies podkreśla, że doświadczenia wojenne Hitlera „miały niewątpliwy wpływ na patologiczny przebieg jego dalszej kariery", a wojenne doświadczenie walczących z nim pod Langemarck jest ,symbolem istotnej psychologicznej

17 Na temat szczegółów dotyczących udziału Mussoliniego w I wojnie światowej zob. G. Hägg, Mussolini. Butny faszysta, Warszawa 2015, s. 72.

18 Pisze o tym Thomas Weber w książce Pierwsza wojna Hitlera. Adolf Hitler, żotnierze pułku Lista i pierwsza wojna światowa (Poznań 2011, passim, fotografia na s. 256). 
więzi, jaka łączy rzezie pod Ypres i pod Verdun oraz londyński Blitz, Warszawę i Stalingrad" 19 .

O wielu działaczach i aktywistach narodowego socjalizmu możemy przeczytać, że byli wybitnymi i walecznymi uczestnikami I wojny, a po niej nie potrafili znaleźć sobie miejsca w życiu. Z pewnością można to powiedzieć o Hermannie Göringu, który jako doskonały pilot, dowódca słynnej eskadry myśliwców Richthofena, wielokrotnie odznaczany w czasie wojny, jak pisze Eatwell - , ,nie potrafiąc przystosować się do życia w powojennych Niemczech, przystąpił do partii nazistowskiej po spotkaniu z Hitlerem w 1922 roku"20. Ponadto Eatwell przypomina:

British Fascisti zostali założeni w maju 1923 roku przez Rothę Linton Orman, młodą kobietę, której wielu przodków służyło w armii. Podczas wojny była kierowcą ambulansu w Serbii, trudno jej było przystosować się do życia w wiejskim Sommerset. Wobec tego Orman zamieściła ogłoszenie w małym prawicowym czasopiśmie. Apelowała do wszystkich, którzy podzielali jej pogląd, że kraj wkrótce opanują bolszewicy, by przyłączyli się do niej i stanęli do obrony ${ }^{21}$.

Partia ta przeszła potem skomplikowaną ewolucję zanim ostatecznie jej wodzem i twarzą został Oswald Mosley ${ }^{22}$.

Dotyczy to nie tylko przywódców. W Niemczech młodzi ludzie, zmobilizowani podczas wojny, mieli wpojone przekonanie, że właściwie Niemcy tylko się bronili, zarazem jednak byli edukowani w duchu poświęcenia dla ojczyzny. Badania nad postawami intelektualistów, członków SS, przeprowadzone przez Christiana Ingrao wskazują, że wojnę już nawet ci najmłodsi traktowali jako pewien rodzaj transcendencji. Zacytował on taki oto list z 1915 r. napisany na Dzień Matki przez syna:

Moja droga matko, muszę napisać całkiem specjalny list i spróbować wyrazić to, co chciałbym powiedzieć. Trochę na pocieszenie, gdyż [...] Erich również dołączył do ludzi, którzy poświęcili swoją krew i odwagę na rzecz budowy przyszłych wielkich Niemiec.

19 N. Davies, Europa. Rozprawa historyka z historią, Kraków 1998, s. 261-262. Davies zamieścił nawet specjalną kasetkę o Langemarck. Poległo tam 25 tys. niezidentyfikowanych niemieckich żołnierzy, a Hitler był tego świadkiem. Dodał też: ,»W Wspaniałe przeżycia« Hitlera w transzejach, gdzie przez cztery lata pędził zachwycający żywot dzielnego Meldegangera, czyli »pułkowego gońca«, miały niewątpliwy wpływ na patologiczny przebieg jego dalszej kariery. Udręczony widokiem losu poległych i rannych towarzyszy, a także ogromnej ofiary Niemców, której jedynym efektem była klęska, postanowił pomścić ich śmierć; upokorzyć z kolei tych, którzy pokonali Niemcy; sprawić, aby Niemcy mogli się znowu poczuć lepsi, dumni, pełni nienawiści, bezlitośni. Ślubowanie zemsty znalazło żywy oddźwięk w milionach zranionych niemieckich serc”.

20 R. Eatwell, Faszyzm. Historia, Poznań 1999, s. 190.

21 Ibidem, s. 287.

22 Poza thumaczeniem biografii Mosleya pióra angielskiego historyka Skidelsky’ego, najlepszym opracowaniem na temat Mosleya w języku polskim jest Macieja Cesarza Od ,Większej Brytanii" do zjednoczonej Europy. Faszystowska doktryna Oswalda Mosleya (Wrocław 2006). Zob. także: ibidem, s. 72-73 (uwagi na temat Orman i jej ruchu). 
Wojna pokazała nam wyraźnie, że nasze życie ma inny sens aniżeli stąpanie po zwykłych ścieżkach rodzinnego, mieszczańskiego życia. Nasze życie przyczynia się do realizacji wielkiego, świętego celu. My nie znamy tego celu. Jest w nas wszczepiony od zarania i prowadzi nas ku czemuś wielkiemu, wiecznemu, czujemy to.

Bóg wytycza teraz wielkie drogi światowej historii, a my jesteśmy wybrańcami, narzędziem, które wybrał. Czy rzeczywiście i naprawdę powinniśmy być szczęśliwi? Wokół mnie wszystko zieleni się i kwitnie, i ptaki z przesadną radością czczą jasność. Jakże piękniejsza i lepsza będzie wiosna po wielkiej wojnie! $!^{23}$

Najważniejsze jednak stało się ukazanie wojny jako czegoś chwalebnego, wspaniałego, jako przeżycia wspólnotowego, szlachetnego. W warstwie ideologii wojna - w przeciwieństwie do klasycznego ujęcia, że jest czymś nadzwyczajnym - teraz stała się czymś najbardziej szlachetnym. Oczywiście można powiedzieć, że już w starożytności powstawały opisy heroizmu oraz pochwała męstwa i odwagi, jednakże po I wojnie światowej zmieniło się to w coś masowego - w żądanie, by każdy był wojownikiem, by każdy był wspaniałym żołnierzem. Przypomnę tutaj fragment z Doktryny faszyzmu Mussoliniego:

Faszyzm przede wszystkiem, o ile chodzi w ogólności o przyszłość i rozwój ludzkości, niezależnie od wszelkich rozważań, dotyczących polityki bieżącej, nie wierzy w możliwość ani też użyteczność wieczystego pokoju. Odrzuca więc pacyfizm, który ukrywa zrzeczenie się walki i upodlenie - w obliczu ofiary. Jedynie wojna wznosi do maksimum napięcia wszystkie siły ludzkie i znaczy znamieniem szlachectwa narody, które mają odwagę stawić jej czoło. Wszelkie inne doświadczenia są tylko namiastkami, które nie stawiają nigdy człowieka przed sobą samym w alternatywie życia i śmierci. Dlatego też doktryna, która wychodzi od postawionego z góry postulatu pokoju, jest obca faszyzmowi; tak jak obce są duchowi faszyzmu, chociaż przyjmowane przezeń dla tej odrobiny korzyści, którą mogą przynieść w danych sytuacjach politycznych, wszystkie konstrukcje o charakterze międzynarodowo-zrzeszeniowym, które, jak wykazuje historia, mogą rozwiać się, gdy pierwiastki uczuciowe, ideowe i praktyczne rozpętają burzę w sercu narodów. Tego ducha antypacyfistycznego faszyzm przenosi także w życie jednostek ${ }^{24}$.

Piotr Podemski w znakomitym studium Giovinezza. Młodzież i mit młodości w faszystowskich Włoszech zwrócił uwagę, że kult walki i wojny bardzo wcześnie powiązano z kultem młodości, co szczególnie podkreślał Gabriele D’Annunzio, który w mowie z 5 maja 1915 r. powiedział:

Czegóż chcecie, Genueńczycy? Czegóż chcecie, Włosi? By naród malał czy rósł? Chcecie większej Italii, nie przez nabywanie, a przez zdobywanie, nie na miarę wstydu, ale za cenę krwi

${ }^{23}$ Ch. Ingrao, Wierzyć i niszczyć. Intelektualiści w machinie wojennej SS, Wołowiec 2013, s. 25. Ingrao wraz z innymi badaczami zajmuje się rolą przeżyć wojennych w wykształceniu ideologów nazistowskich, wyrzucając historykom niemieckim nadmierny funkcjonalizm (ibidem, s. 13).

24 B. Mussolini, Doktryna faszyzmu, Lwów 1935, s. 22. 
i chwały. Fiat! Fiat! Niech się stanie! Niech się dokona! Niech żyje uzbrojony Święty Jerzy! Niech żyje sprawiedliwa wojna! Niech żyje większa Italia!25

Joanna Sondel-Cedarmas bardzo obszernie przedstawiła stanowisko D'Annunzia wobec postanowień traktatu wersalskiego oraz podała szereg argumentów, które poeta wysunął, by uzasadnić pojęcie „okaleczonego zwycięstwa”26.

Dotyczy to także intelektualnej podbudowy faszyzmów. Jak pisał Eatwell:

Chociaż istnieją ważne przesłanki, by poszukiwać intelektualnych źródeł faszyzmu w okresie przed 1914 rokiem, jest pewne, że wojna odegrała zasadniczą rolę w pojawieniu się pierwszych większych ruchów faszystowskich. Jej oddziaływanie było ogromne nawet na płaszczyźnie idei. Dla przykładu: wielu syndykalistów doszło do przekonania, że to raczej nacjonalizm, a nie strajk generalny klasy robotniczej jest tym mobilizującym mitem, którego poszukiwali. Czasami wiązało się to z przekonaniem, że wojna pokazała wielką potęgę państwa w przeprowadzaniu rewolucji społecznej. Osoby o większych inklinacjach konserwatywnych twierdziły, że wojna zagwarantuje rozwój gospodarczy pozwalający na sfinansowanie reform, które pozwolą „wykupić się” od groźby lewicowej rewolucji (która przeraziła wielu przedstawicieli prawicy po sukcesie bolszewików w 1917 roku). Nie ulega wątpliwości, że wojna zakwestionowała wiarę w stare elity i kluczowe wartości, takie jak religia, które pomagały utrzymywać stary porządek ${ }^{27}$.

Pierwsza wojna światowa była bardzo wyraźnym punktem odniesienia, co więcej - widoczny stał się kult wojny, walki, odwagi; tchórzami nazywano tych, którzy propagowali pacyfizm. Wielu socjologów zwracało uwagę na kult cmentarzy; wydawano albumy ze zdjęciami mogił, na których często umieszczano fotografie poległych żołnierzy. Jak słusznie zauważył jeden z bardziej wnikliwych badaczy, wszystko było estetyczne, uwznioślone, a o tym, co tak naprawdę kryły okopy, o brudzie, robactwie czy cierpieniu - nie pisano; mówiono o heroizmie, ale nie o strachu. Śmierć dla ojczyzny stała się piękna i estetyczna ${ }^{28}$.

W Niemczech wojna i jej rezultat stały się przedmiotem propagandy legendy o ciosie w plecy. Nader często uznawano, że za wszystkim stoją Żydzi, bo zapewnili sobie równe prawa, najbardziej się wzbogacili albo dlatego, że nie walczyli w wojnie.

W przemówieniach z 1920 i 1921 r., wygłoszonych w Trieście i Mediolanie, Mussolini bardzo wyraźnie to podkreślał:

25 Cyt. za: P. Podemski, Giovinezza. Młodzież w faszystowskich Włoszech, Warszawa 2010, s. 42-43. Notabene rozdział o poecie autor zatytułował Gabriele D'Annunzio jako princeps juventutis (ibidem, s. 39).

26 Zob. J. Sondel-Cedarmas, Gabriele D'Annunzio. Uźródet ideologicznych włoskiego faszyzmu, Kraków 2008, s. 127-134.

27 R. Eatwell, op. cit., s. 54.

28 Por. W. Benjamin, Teorie niemieckiego faszyzmu. O pracy zbiorowej pt. Wojna i wojujacy, pod red. Ernsta Jüngera, [w:] Wobec faszyzmu, s. 24-37. Autor ostro skrytykował gloryfikację wojny w omawianej przez siebie publikacji. 
Walka jest początkiem wszech rzeczy, ponieważ życie całe jest pełne sprzeczności; jest w nim miłość i nienawiść, biel i czerń, dzień i noc, dobro i zło, i dopóki te przeciwieństwa nie zniosą się wzajemnie i nie przejdą w stan równowagi, walka tkwić będzie zawsze w głębi natury ludzkiej jako ostateczne przeznaczenie.

\section{A dalej pochwalał taki stan rzeczy:}

A zresztą dobrze jest, że jest tak właśnie. Dziś może toczyć się walka wojenna, ekonomiczna, ideowa, ale dzień, w którym by się już nie walczyło, byłby dniem melancholii, kresu i ruiny. Otóż dzień ten nie nadejdzie. Właśnie dlatego, ponieważ historia przedstawia się jako zmieniająca się panorama. Gdyby się miało zamiar powrócić do ciszy, do spokoju i spokojności, trzeba by zwalczać obecne dążności współczesnego dynamicznego okresu. Trzeba przygotować się na inne niespodzianki, na inne walki. I nie nastanie era pokoju, póki narody będą się oddawać chrześcijańskiemu marzeniu o powszechnem braterstwie i o podaniu sobie rąk poprzez oceany i góry ${ }^{29}$.

Eatwell napisał znamienne słowa: „Po zniszczeniu lewicowych i innych opozycyjnych partii w latach 1922-1925 Włochy miały stać się gigantycznym billbordem pełnym haseł typu: »Wojna jest tym dla mężczyzny, czym rodzenie dzieci dla kobiety« $\mathrm{i} »$ Lepiej żyć przez jeden dzień jak lew niż sto lat jak owca«"30. Nie było też zapewne przypadkiem, że w pierwszym zebraniu założycielskim włoskich $\mathrm{Fa}$ sci di Combattimento, przekształconych później w Narodową Partię Faszystowską, wziął udział Filippo Marinetti, autor opublikowanego już w 1909 r. Manifestu futurystycznego, który zawierał jednoznaczną apoteozę wojny w słowach: „Chcemy sławić wojnę - jedyną higienę świata - militaryzm, patriotyzm, gest niszczycielski anarchistów, piękne idee, za które się umiera, oraz pogardę dla kobiet”31.

Przejawem wpływu wojny było też tworzenie oddziałów paramilitarnych. To zjawisko towarzyszyło nawet tym najmniejszym z ruchów faszystowskich zawsze były jakieś oddziały zbrojne albo udające uzbrojone, zawsze były jakieś oddziały specjalne, we Włoszech nawet umundurowanie wzorowano na mundurach arditi, czyli elitarnych oddziałach z okresu I wojny światowej, nawet faszyści brytyjscy mieli takie oddziały dzielnych chłopców (nazwane Biff Boys), a w 1926 r. ubrali się w niebieskie koszule. Umundurowanie stało się istotnym wyróżnikiem ruchów faszystowskich, obecne było w każdym, nawet najmniejszym ruchu, podobnie jak odznaki, opaski czy inne symbole, które miały przypominać sztandary wojskowe i wskazywać na hierarchię w organizacji. Zabicie przeciwnika i ryzyko własnej śmierci często nie stanowiło problemu. Najbardziej wyrazistym przykładem była działalność Legionu Michała Archanioła. Badaczka rumuńskiego faszyzmu pisze o morderstwach dokonywanych w biały dzień -

29 B. Mussolini, op. cit., s. 46, pkt 4.

30 R. Eatwell, op. cit., s. 39.

31 E. Grabska, H. Morawska, F.T. Marinetti, Manifest futurystyczny, [w:] Artyści o sztuce, Warszawa 1977, cyt. za: R. Eatwell, op. cit., s. 88-89. 
Codreanu zabił w 1924 r. prefekta policji w Jassach, liberalny premier Ion C. Duca w 1933 r. został zastrzelony przez trzech legionistów, w 1939 r. zabito polityka Armanda Câlinescu. Autorka dodaje, iż „Wykonując zalecenie swego »Kapitana« [sc. Codreanu - M.Z.], większość tych sfanatyzowanych katów zgłosi się na policję po dokonaniu zbrodni; w ten sposób pójdą z kolei na śmierć setki młodych legionistów"32.

Niezaprzeczalny jest fakt, że było wielu prekursorów myślenia w kategoriach siły i przemocy, z których najbardziej znany to bez wątpienia Georges Sorel, propagujący w swoich Réflexions sur la violence ideę strajku powszechnego skojarzoną z użyciem siły. Jest u Sorela wiele fragmentów wskazujących na wspaniałość i szlachetność wojny. Byli też liczni darwiniści, z których dokonań czerpał Hitler, który potem stworzył ideę walki ras, pojmując tę walkę jako wojnę. Można jednak zasadnie sądzić, że bez I wojny światowej i jej skutków ruchy faszystowskie nie powstałyby tak masowo, a Sorel mógłby głosić swoje teorie w małym kółku Circle Proudhon. Wojna stała się katalizatorem, a jej skutki stworzyły możliwość działania tym, dla których I wojna światowa była wzorcem rozwiązywania wielkich problemów społecznych i stwarzania nowej rzeczywistości politycznej. Anda Rottenberg, kuratorka wystawy poświęconej II wojnie światowej, udzielając wywiadu powiedziała, że zorganizowała ją po to, ,żeby ludzie zdali sobie sprawę, jak wyniszczająca jest wojna i że nawet gdy się skończy, nie można się z niej już nigdy wyleczyć"33. Dzieje ruchów faszystowskich w dwudziestoleciu międzywojennym potwierdzają, że z I wojny światowej też trudno było się wyleczyć.

\section{BIBLIOGRAFIA}

Aristide Briand, la Société des Nations et l'Europe 1919-1932. Publié sous la direction de Jacques Bariéty, Strasbourg 2007.

Baranowska M., Nazizm kontra Nietzsche, „Studia nad Faszyzmem i Zbrodniami Hitlerowskimi” 2008, t. 30 .

Benjamin W., Teorie niemieckiego faszyzmu. O pracy zbiorowej pt. Wojna i wojujacy, pod red. Ernsta Jüngera, [w:] Wobec faszyzmu, wyb. i wstęp H. Orłowski, Warszawa 1987.

Cesarz M., Od „Większej Brytanii” do zjednoczonej Europy. Faszystowska doktryna Oswalda Mosleya, Wrocław 2006.

Chioveanu M., Sacralizing the Nation. The Political Messianism of the Legion "Archangel Michael", [w:] Vers un profil convergent des fascisms. "Nouveau consensus " et la religion politique en Europe centrale, sous la dir. de Traian Sandu, Paris 2010.

Davies N., Europa. Rozprawa historyka z historia, Kraków 1998.

Eatwell R., Faszyzm. Historia, Poznań 1999.

Faszyzmy europejskie (1922-1945) w oczach wspótczesnych i historyków, wyb. i wstęp J.W. Borejsza, Warszawa 1979.

32 A. Laignel-Lavastine, Cioran, Eliade, Ionesco: o zapominaniu faszyzmu. Trzech intelektualistów rumuńskich $w$ dziejowej zawierusze, Kraków 2010, s. 91.

33 M. Urbaniak, Wywiad z Anda Rottenberg, „Wysokie Obcasy”, 18.08.2018, nr 32(995), s. 12. 
Hägg G., Mussolini. Butny faszysta, Warszawa 2015.

Ingrao Ch., Wierzyć i niszczyć. Intelektualiści w machinie wojennej SS, Wołowiec 2013.

Kracauer S., Ornament z ludzkiej masy, [w:] Wobec faszyzmu, wyb. i wstęp H. Orłowski, Warszawa 1987.

Laignel-Lavastine A., Cioran, Eliade, Ionesco: o zapominaniu faszyzmu. Trzech intelektualistów rumuńskich w dziejowej zawierusze, Kraków 2010.

Lefebvre G., Pouthas Ch.H., Baumont M., Historia Francji, t. 2: Od 1774 do czasów wspótczesnych, Warszawa 1969.

Maftei-Bourbonnais M.M., Cioran, compagnon de route de la Garde de Fer, [w:] Vers un profil convergent des fascisms. "Nouveau consensus » et la religion politique en Europe centrale, sous la dir. de Traian Sandu, Paris 2010.

Markiewicz H., Romanowski A., Skrzydlate słowa. Wielki słownik cytatów polskich i obcych, Kraków 2005.

Mussolini B., Doktryna faszyzmu, Lwów 1935.

Ortega y Gasset J., Bunt mas i inne pisma socjologiczne, Warszawa 1982.

Paxton R.O., Anatomia faszyzmu, Poznań 2005.

Payne S., Fascism. Comparison and Definition, Madison 1980.

Podemski P., Giovinezza. Młodzież w faszystowskich Włoszech, Warszawa 2010.

Rosenberg A., Novemberköpfe, München 1927.

Seidler M., Hungary and the League of Nations, [w:] Der Traum vom Frieden - Utopie oder Realität? Kriegs- und Friedensdiscurse aus historischer, politologischer und juristischer Perspektive (1914-2014), Hrsg. E. Dácz, Ch. Griessler, H. Kovács, Budapest 2016.

Sondel-Cedarmas J., Gabriele D’Annunzio. U źródet ideologicznych włoskiego faszyzmu, Kraków 2008.

Sorel G., Réflexions sur la violence, Paris 1925.

Sternhell Z., La droite révolutionnaire, 1885-1914: les origines françaises du fascisme, Paris 1978.

Urbaniak M., Wywiad z Anda Rottenberg, „Wysokie Obcasy”, 18.08.2018, nr 32(995).

Weber T., Pierwsza wojna Hitlera. Adolf Hitler, żolnierze putku Lista i pierwsza wojna światowa, Poznań 2011.

Zmierczak M., Der Einfluss des Ersten Weltkrieges auf die Entwicklung des Völkerrechts, [w:] Der Traum vom Frieden - Utopie oder Realität? Kriegs- und Friedensdiscurse aus historischer, politologischer und juristischer Perspektive (1914-2014), Hrsg. E. Dácz, Ch. Griessler, H. Kovács, Budapest 2016.

Zmierczak M., Spory o istotę faszyzmu. Dzieje i krytyka, Poznań 1988.

\section{SUMMARY}

The First World War and its consequences constituted the soil, on which the fascists movements rose in all European countries, gathering people mainly on the basis of discontent and disagreement with the Treaty of Versailles. On the one hand, after the end of multinational imperial state, promise to respect the right of every nation to self-ruling was a popular idea; on the other hand, the Treaty of Versailles did not always respect the idea, e.g. in case of Slovakia, Austria or Hungarian. The so-called little treaty, concerning the minorities, was also treated as non-equal position of nation. The fascists movements based on this and began not only to identify everyone on the basis of national identity, but also to glorify war as a unique experience, as an example of heroism, something much better than pacifism. This idea was fundamental in education, beginning with children. It seems also very important to underline the fact, that most of the charismatic leaders of fascists movements personally took part in the First World War, treating the war as a splendid example of national community, it was the case not only of Mussolini and Hitler. The dream that the Treaty concluded 
after the Great War will be a guarantee of eternal peace, from the very beginning was contested by fascist movements, leading in the end to the Second World War.

Keywords: fascists movements; discontent with the Treaty of Versailles; glorification of war as a noble and heroic experience of human activity; fascist charismatic leaders and their personal experience of war

\section{STRESZCZENIE}

Pierwsza wojna światowa i jej skutki stanowiły podłoże, na którym w całej Europie wyrosły ruchy faszystowskie, zarówno faszyzm włoski, jak i niemiecki nazizm, belgijski reksizm, węgierscy strzałokrzyżowcy i inni. Chociaż tylko nieliczne zdobyły władzę, wszystkie jednak odwoływały się do programu walki ze skutkami wojny, najczęściej dążąc do nowej wojny. $Z$ jednej strony I wojna światowa, która wywołała rozpad wielkich wielonarodowych imperiów, a w której padło hasło samostanowienia narodów, wymagała zdecydowanej identyfikacji jednostki ze względu na przynależność narodową, z drugiej zaś traktat wersalski nie zawsze respektował te narodowe dążenia, jak w przypadku Słowacji, Austrii czy Węgier. Niezadowolenie z ładu powojennego było istotnym podłożem dla ruchów faszystowskich. Drugim elementem była gloryfikacja i rehabilitacja wojny jako przeciwieństwa tchórzliwego pacyfizmu, jako wspaniałej postawy narodowej. W tym duchu wychowywano młodzież, a nawet dzieci. Wreszcie - co trzeba podkreślić - większość charyzmatycznych przywódców rozmaitych ruchów faszystowskich brała udział w I wojnie światowej, odbierając ją jako wielkie przeżycie wspólnoty. Dotyczyło to nie tylko Mussoliniego czy Hitlera. Pragnienie, by ład wersalski był ładem trwałym, od początku było zatem skazane na kontestację. W tej roli wystąpili faszyści, którzy doprowadzili do II wojny światowej.

Słowa kluczowe: ruchy faszystowskie; niezadowolenie z traktatu wersalskiego; pochwała wojny jako szlachetnego i bohaterskiego fenomenu; przywódcy faszystowscy i ich doświadczenie wojny 